\#38380705
$\mathrm{ctm}$

\title{
Water Quality Research Program
}

compiled by Richard E. Price, Jeffery P. Holland, Robert C. Gunkel, Jr.

U.S. Army Corps of Engineers

Waterways Experiment Station

3909 Halls Ferry Road

Vicksburg, MS 39180-6199

Final report

Approved for public release; distribution is unlimited
WATE!T PESOURCES

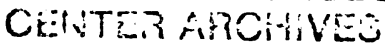

FEB $\because:$

UNIVERSITY OF CALIFCR VIA BER'XELSY

\section{Prepared for U.S. Army Corps of Engineers \\ Washington, DC 20314-1000}

